AperTO - Archivio Istituzionale Open Access dell'Università di Torino

\title{
Comparative analysis of the prion protein (PrP) gene in cetacean species
}

\section{This is the author's manuscript}

Original Citation:

\section{Availability:}

This version is available http://hdl.handle.net/2318/40432

since

Terms of use:

Open Access

Anyone can freely access the full text of works made available as "Open Access". Works made available under a Creative Commons license can be used according to the terms and conditions of said license. Use of all other works requires consent of the right holder (author or publisher) if not exempted from copyright protection by the applicable law. 


\title{
Comparative analysis of the prion protein $(\operatorname{Pr} P)$ gene in cetacean species
}

\author{
Pier Luigi Acutis ${ }^{\mathrm{a}, *}$, Simone Peletto ${ }^{\mathrm{a}}$, Elena Grego ${ }^{\mathrm{b}}$, Silvia Colussi ${ }^{\mathrm{a}}$, Maria Vittoria Riina ${ }^{\mathrm{a}}$, \\ Sergio Rosati ${ }^{\mathrm{b}}$, Walter Mignone ${ }^{\mathrm{c}}$, Maria Caramelli ${ }^{\mathrm{a}}$ \\ ${ }^{a}$ CEA (National Reference Centre for TSEs), Istituto Zooprofilattico Sperimentale del Piemonte, Liguria e Valle d'Aosta, via Bologna 148, 10154 Turin, Italy \\ ${ }^{\mathrm{b}}$ Department of Animal Productions, Epidemiology and Ecology, Faculty of Veterinary Medicine, University of Turin, Grugliasco, Italy \\ ${ }^{\mathrm{c}}$ Department of Imperia, Istituto Zooprofilattico Sperimentale del Piemonte, Liguria e Valle D'Aosta, Imperia, Italy
}

Received 29 August 2006; received in revised form 4 December 2006; accepted 18 December 2006

Available online 12 January 2007

Received by M. Di Giulio

\begin{abstract}
The partial $\operatorname{Pr} P$ gene sequence and the deduced protein of eight cetacean species, seven of which have never been reported so far, have been determined in order to extend knowledge of sequence variability of the $\operatorname{Pr} P$ genes in different species and to aid in speculation on cetacean susceptibility to prions. Both the nucleotide and the deduced amino acid sequences have been analysed in comparison with some of the known mammalian PrPs. Cetacean PrPs present typical features of eutherian PrPs. The PrP gene from the species of the family Delphinidae gave identical nucleic acid sequences, while differences in the $\operatorname{Pr} P$ gene were found in Balaenopteridae and Ziphidae. The phylogenetic tree resulting from analysis of the cetacean $\operatorname{Pr} P$ gene sequences, together with reported sequences of some ungulates, carnivores and primates, showed that the $\operatorname{Pr} P$ gene phylogenesis mirrors the species phylogenesis. The $\operatorname{Pr} P$ gene of cetaceans is very close to species where natural forms of TSEs are known. From an analysis of the sequences and the phylogenesis of the PrP gene, susceptibility to or occurrence of prion diseases in cetaceans can not be excluded.
\end{abstract}

(C) 2007 Elsevier B.V. All rights reserved.

Keywords: Transmissible spongiform encephalopathies; Maritime mammals; Polymorphism; Multiple sequence alignment; Phylogenetic tree

\section{Introduction}

The prion protein $\left(\mathrm{PrP}^{\mathrm{C}}\right)$ is a cellular glycoprotein formed by a largely unstructured and flexible $\mathrm{N}$-terminus and by a $\mathrm{C}$-terminus forming a more rigid globular domain, with regions of secondary structure (three $\alpha$-helices and a short, two-stranded, anti-parallel $\beta$-sheet). A segment of usually five or six repeats is incorporated

Abbreviations: Acc. no., GenBank accession number; Asn, asparagine; Asp, aspartic acid; BSE, bovine spongiform encephalopathy; cDNA, DNA complementary to RNA; CJD, Creutzfeldt-Jakob disease; CWD, chronic wasting disease; dNTP, deoxyribonucleoside triphosphate; FSE, feline spongiform encephalopathy; GPI, glycosyl-inositol-phospholipid; GSS, GerstmannStraussler-Scheinker disease; H1, $\alpha$-helix 1; H2, $\alpha$-helix 2; IUCN, International Union for Conservation of Nature and Natural Resources; ORF, open reading frame; PCR, polymerase chain reaction; PrP, prion protein; $\operatorname{Pr} P$, prion protein gene ( $\operatorname{Pr} P$ gene); Ser, serine; TSE, transmissible spongiform encephalopathy.

* Corresponding author. Tel.: +39 011 2686245; fax: +39 0112686322.

E-mail address: pierluigi.acutis@izsto.it (P.L. Acutis). in the N-terminal region (Hunter et al., 1994; Premzl et al., 2000). A disulfide bridge and two variably occupied N-linked glycosylation sites are involved in stabilization of the C-terminal domain (Maiti and Surewicz, 2001; Rudd et al., 2001). $\operatorname{PrP}^{\mathrm{C}}$ is attached to the cell membrane surface by a glycosyl-inositolphospholipid (GPI) anchor (Stahl et al., 1990). The function of $\mathrm{PrP}^{\mathrm{C}}$ is not clear, but it seems to be implicated in copper binding (Brown et al., 1997) and copper transport and metabolism (Pauly and Harris, 1998). Imidazol nitrogens of the histidines in the repeat region and histidines at positions 96 and 111 are thought to bind $\mathrm{Cu}^{2+}$ ions, thus adding structure to the flexible repeat region (Viles et al., 1999). $\operatorname{PrP}^{\mathrm{C}}$ is expressed in most tissues, but the highest levels are found in the central nervous system, notably associated with synaptic membranes. $\operatorname{PrP}^{\mathrm{C}}$ is encoded by the $\operatorname{PrP}$ gene $(\operatorname{Pr} P)$ which is present in a single copy and contains the entire open reading frame (ORF) within a single exon (Oesch et al., 1985; Martin et al., 1995; Prusiner, 1991). The $\operatorname{Pr} P$ gene seems to be present in all higher species, including mammals, 
avians, reptiles and fish. $\operatorname{PrP}^{\mathrm{C}}$ is linked to the occurrence of transmissible spongiform encephalopathies (TSEs) or prion diseases, a group of fatal neurodegenerative diseases that affect humans and other mammals. Prion diseases are characterized by the post-translational conversion of the $\operatorname{PrP}^{\mathrm{C}}$ to a conformationally abnormal isoform $\left(\mathrm{PrP}^{\mathrm{Sc}}\right.$ ) (Weissmann, 1999) that accumulates in the nervous system. $\operatorname{PrP}^{\mathrm{Sc}}$ is characterized by an increased $\beta$-sheet content and by an increased resistance to proteases (Prusiner, 1982). It has been shown that only organisms expressing $\mathrm{PrP}^{\mathrm{C}}$ are susceptible to TSEs (Bueler et al., 1993). A molecule other than PrP, designated "protein X", is believed to be involved in the conversion of $\operatorname{PrP}^{\mathrm{C}}$ to $\operatorname{PrP}^{\mathrm{Sc}}$ (Telling et al., 1995). Natural prion diseases may occur as genetic, infectious or sporadic disorders in a variety of mammals, most notably in humans, sheep, cattle and deer. TSEs include Creutzfeldt-Jakob disease (CJD) in humans, scrapie in sheep and goats, chronic wasting disease (CWD) in deer and bovine spongiform encephalopathy (BSE) in cattle. The BSE agent crossed the species barrier, causing feline spongiform encephalopathy (FSE) in domestic and wild cats (Kirkwood and Cunningham, 1994) and variant CJD in human beings (Aguzzi et al., 2001). The species barrier is an important aspect in the risk of prion oral transmission. Studies using transgenic mice have shown that the species barrier might be related to the degree of sequence homology between the prion protein in different species (Scott et al., 1993), in both the amino acid sequence of the protein and its tridimensional conformation (Prusiner, 1998). This indicates that certain polypeptide segments of the prion protein seem to have a particularly large influence on the species barrier (Schätzl et al., 1995; Billeter et al., 1997; Vorberg et al., 2003) and that variability at these sites can create a "host barrier", even between related species (Kocisko et al., 1995; Telling et al., 1994; Horiuchi et al., 2000).

In human beings, sheep and deer, the expression of prion diseases is influenced by polymorphisms of the host's prion protein gene. In humans, inherited TSEs are caused by diseaseassociated coding mutations and insertions of different numbers of octarepeat units. In sporadic CJD, the polymorphism at codon 129, resulting in either methionine or valine, has a profound influence on susceptibility and phenotypic expression of this disease (Johnson and Gibbs, 1998). Methionine homozygosity at the same codon has also been found in all clinical cases of variant CJD (Peden and Ironside, 2004).

In sheep, amino acid changes at codons 136, 154 and 171 have been shown to be associated with susceptibility to scrapie: $\operatorname{PrP}$ allelic variants valine/arginine/glutamine (VRQ) and alanine/arginine/glutamine (ARQ) at codons 136, 154, 171, respectively, are generally associated with high susceptibility to scrapie, whereas the ARR allele has been linked to decreased susceptibility or even resistance (Belt et al., 1995; Bossers et al., 1996). In elk, the Met/Met132 genotype has been indicated as a predisposing factor to both natural and experimental CWD (O'Rourke et al., 1999; Hamir et al., 2006).

The $\operatorname{Pr} P$ gene has been characterized in various species of mammals and birds (Gabriel et al., 1992; Martin et al., 1995; Wopfner et al., 1999; Zhang et al., 2002; van Rheede et al., 2003; Lysek et al., 2004; Wu et al., 2006), and corresponding
cDNA has been identified in the turtle (Simonic et al., 2000) and Xenopus laevis (Strumbo et al., 2001). Analysis of amino acid sequences showed a high level of identity within mammals and within birds, whereas between birds and mammals the overall identity is low (Wopfner et al., 1999). Cloned and sequenced peacock and parakeet prion genes show conservation of the structural features of all known mammalian and avian PrPs (Yang et al., 2005). Different cDNAs coding for homologs of tetrapod $\mathrm{PrP}^{\mathrm{C}}$ have been identified also in Fugu rubripes (Suzuki et al., 2002; Rivera-Milla et al., 2003), Atlantic salmon (Salmo salar) (Oidtmann et al., 2003) and zebrafish (Danio rerio) (Cotto et al., 2005).

Even though $\operatorname{Pr} P$ sequences for many species are available from public databases, the $\operatorname{Pr} P$ gene sequence of cetaceans has not yet been well characterized. Sequences for only two species are available on GenBank: the complete $\operatorname{Pr} P$ open reading frame of Tursiops truncatus (bottle-nose dolphin) consisting of 774 nucleotides encoding 257 amino acids (GenBank acc. no. AY964056) and the partial $\operatorname{Pr} P$ sequences of Physeter catodon (sperm whale) (GenBank acc. nos. AY133054 and AF117311). Moreover, cetaceans suffer from a lack of phylogenetic information that also mirrors the paucity of data on other aspects of their biology. This is illustrated by the fact that $56 \%$ of delphinids and $75 \%$ of ziphiids are categorised as data deficient in the International Union for Conservation of Nature and Natural Resources (IUCN) Red List of threatened species (www.redlist.org).

To extend knowledge of $\operatorname{Pr} P$ gene sequence variability in different species and to aid in speculation on cetacean susceptibility to prions, we have determined and analysed the prion genes of eight cetacean species. Both the nucleotide and the deduced amino acid sequences have been compared with some known mammalian PrPs.

\section{Materials and methods}

\subsection{Molecular biology}

Genomic DNA was isolated from $25 \mathrm{mg}$ of frozen muscle tissue of Balaenoptera physalus (finback whale, 1 specimen), Ziphius cavirostris (Cuvier's beaked whale, 1 specimen), T. truncatus (bottle-nose dolphin, 2 specimens), Steno bredanensis (rough-toothed dolphin, 1 specimen), Grampus griseus (Risso's dolphin, 2 specimens), Globicephala melas (longfinned pilot whale, 1 specimen), Delphinus delphis (saddleback dolphin, 1 specimen) and Stenella coeruleoalba (striped dolphin, 4 specimens) using the DNeasy Tissue Kit (Qiagen). All the samples were collected from animals stranded on the Italian coasts. Liver and cutis/subcutis tissues were available for some species and total DNA was purified also from these matrices for data confirmation. DNA concentration was determined by spectrophotometric absorbance measurement.

The polymerase chain reaction (PCR) amplification of the $\operatorname{Pr} P$ gene was performed in two independent laboratories. Following a multiple alignment of over 80 mammalian, avian, reptilian, amphibian and fish $\operatorname{Pr} P$ sequences published on the GenBank database, two degenerate primers were designed on 
highly conserved regions coding for the $\mathrm{N}$ - and $\mathrm{C}$-terminal signal peptides in mammals. The sequences of these primers, which were obtained from Invitrogen (Carlsbad, USA), were: WhaleFOR (+) 5'-TGGATSCTVGTTCTCTTTGTGG-3' and WhaleREV (-) 5'-AATGAGGAARGADATSAGGAGG-3' hybridising on the target $\operatorname{Pr} P$ DNA at corresponding nucleotides 19-40 and 723-744 of human $\operatorname{Pr} P$ ORF (GenBank acc. no. M13899), respectively. Standard conditions for the PCR reactions were: $150 \mathrm{ng}$ of genomic DNA, 50 pmol of each primer, $100 \mu \mathrm{M}$ of dNTPs (Fermentas), 1 unit of Taq polymerase (HotStarTaq, Qiagen) in a final volume of $50 \mu \mathrm{l}$ of buffer consisting of Tris. $\mathrm{Cl}, \mathrm{KCl},\left(\mathrm{NH}_{4}\right)_{2} \mathrm{SO}_{4}$ and $1.5 \mathrm{mM}$ $\mathrm{MgCl}_{2}$. Thermocycling parameters consisted of an initial denaturation step $\left(95{ }^{\circ} \mathrm{C}, 15 \mathrm{~min}\right)$ followed by 40 cycles of denaturation $\left(94{ }^{\circ} \mathrm{C}, 1 \mathrm{~min}\right)$, annealing $\left(58{ }^{\circ} \mathrm{C}, 1 \mathrm{~min}\right)$ and extension $\left(72{ }^{\circ} \mathrm{C}, 1 \mathrm{~min}\right)$ on temperature gradient cyclers (MyiQ, Bio-Rad Laboratories; GeneAmp 9700, Applied Biosystems).

PCR products with the appropriate length were directly purified by the silica column method (QIAquick PCR Purification Kit, Qiagen) or isolated by agarose gel electrophoresis and purified by silica-gel-based filtration (QIAquick Gel Extraction Kit, Qiagen).

\subsection{Cloning and sequencing}

The $\operatorname{Pr} P$ gene sequence was determined by direct DNA sequencing on both strands of the PCR products by Big Dye terminator cycle-sequencing using the amplification primer pair, and analysed on an ABI Prism 3130 Genetic Analyser (Applied Biosystems) according to the manufacturer's protocol. The purified PCR products of $B$. physalus and one $S$. coeruleoalba were cloned into pDRIVE cloning vector (Qiagen) and five recombinant clones were double strand sequenced. The $\operatorname{Pr} P$ gene sequences of the maritime mammals were analysed using the Lasergene package (DNASTAR Inc., Madison, USA) and aligned with the consensus sequence of other known mammals available in the GenBank database. The newly determined cetacean $\operatorname{Pr} P$ sequences have been deposited in the GenBank database under accession numbers DQ884467-DQ884475.

\subsection{Phylogenetic analysis}

Genetic distances were computed using MEGA (Kumar et al., 2004). Distance matrices were determined under the assumptions of Kimura's two-parameter model and were used to infer dendrograms by the neighbor-joining method (Saitou and Nei, 1987). Confidence values for individual branches of the resulting tree were determined by bootstrap analysis with 1000 replicates (Felsenstein, 1981).

\section{Results and discussion}

\subsection{PrP gene sequence and the encoded prion protein}

In this work, the partial $\operatorname{Pr} P$ gene sequence (688 bp, including the ORF of the complete mature protein) of eight cetacean species was determined. Except for those of the bottlenose dolphin, they are novel and expand the collection of known prion genes. Most of these newly analysed species belong to the suborder Odontoceti, which includes the family Delphinidae (5 species) and the family Ziphidae (1 species). B. physalus is also included in this study and belongs to the suborder Mysticeti, family Balaenopteridae. The resulting PrP amino acid sequences are reported in Fig. 1, aligned with other mammalian PrPs (numbering system correlates to the human $\operatorname{PrP})$. The $\operatorname{Pr} P$ gene from the species of the family Delphinidae gave strikingly identical nucleic acid sequences, except for the G. griseus sequence that was heterozygous for a non-coding mutation at codon $69(\mathrm{cac} \rightarrow c a t)$. This inter-species homology was confirmed by multiple DNA extractions and PCR reactions in two different laboratories. The homology can be explained by the relatively recent evolutional divergence of the family Delphinidae: dolphins evolved during the Miocene about 10 million years ago. This separation during the evolution of the families Delphinidae, Balaenopteridae and Ziphidae can also explain the fact that differences in the $\operatorname{Pr} P$ gene were found in B. physalus and Z. cavirostris.

\subsubsection{N-terminal region}

The N-terminal region (proteinase K-sensitive portion of PrP) includes amino acids 1-91 and comprises the signal peptide (amino acids 1-22) and the repeat region (amino acids 51-91).

In the signal peptide, B. physalus carried a cysteine at codon 16 , encoded by the triplet $\operatorname{tgc}$, while all the other maritime mammals presented a tryptophan (triplet $\operatorname{tgg}$ ), like the other considered mammalian species. Codon 19 was characterized by the presence of a methionine, which appeared to be typical of cetaceans: in other mammals it has been reported only in the Asian elephant (van Rheede et al., 2003). At position 21 most mammals carry a leucine, while members of the family Delphinidae a phenylalanine. Codon 21 is located between the consensus residues for the cleavage enzyme and seems to be well conserved in mammals. Along with some other species, dolphins represent an exception: the same substitution has been detected in the $\operatorname{Pr} P$ gene of the mink and the ferret (Wopfner et al., 1999), while valine replaces leucine in the manatee (van Rheede et al., 2003). An L21P polymorphism has been described in caprine $\operatorname{Pr} P$ (Billinis et al., 2002). The residues flanking the signal peptide cleavage site, between cysteine 22 and lysine 23, were perfectly conserved in cetaceans; the presence of glycine 20 and cysteine 22 before the cleavage site agrees with the consensus residues for the cleavage enzyme (Udenfriend and Kodukula, 1995). Cetacean PrP conserved proline at position 44; this residue undergoes 4-hydroxylation and represents an important functional feature of the PrP Nterminal region (Gill et al., 2000). Nevertheless, several mammalian species lack this residue, raising questions as to the universal importance of this modification (van Rheede et al., 2003).

Analysis of the repeat region showed that the number of repeats was five in all examined maritime mammal species. One S. coeruleoalba specimen showed a polymorphism resulting in 
Homo sapiens

Macaca mulatta

ovis aries

Bos taurus

Capra hircus

Hippopotamus amphibius

Hippopotamus

Sus scrofa

Mustela vis

Canis familiaris

Canis familiaris

*hyseter catodon

*ziphius cavirostris

* Stenella coeruleoalba

*Stenella coeruleoalba (1)

*Grampus griseus

* Globicephala mela

*Delphinus delphis

* Steno bredanensis

* Tursiops truncatus

Tursiops truncatus (2)

Tursiops truncatus (3)

Tursiops truncatus (4)

Tursiops truncatus (5)

Homo sapiens

Macaca mulatta

ovis aries

Bos taurus

Capra hircus

Cervus elaphus

Hippopotamus amphibius

Sus scrofa

Mustela viso

Mustela viso

Canis familiaris

Canis familiaris

Physeter catodon

*iphius

*

*

ba (1)

*

Delohinhala melas

Delphinus delphis

Steno bredanensis

Tursiops truncatus

Tursiops truncatus (2)

Tursiops truncatus (3)

Tursiops truncatus (4)

ATWSDLGLCKKRPKPGG-WNTGG-SRYPGQGSPGGNRYPPQGGGWGPHGG-WGQ

\section{TWSDLGLCKKRPKPGG-WNTGG-SRYPGQGSPGGNRYPQGGGGWGQPHGGG-WGQ-}

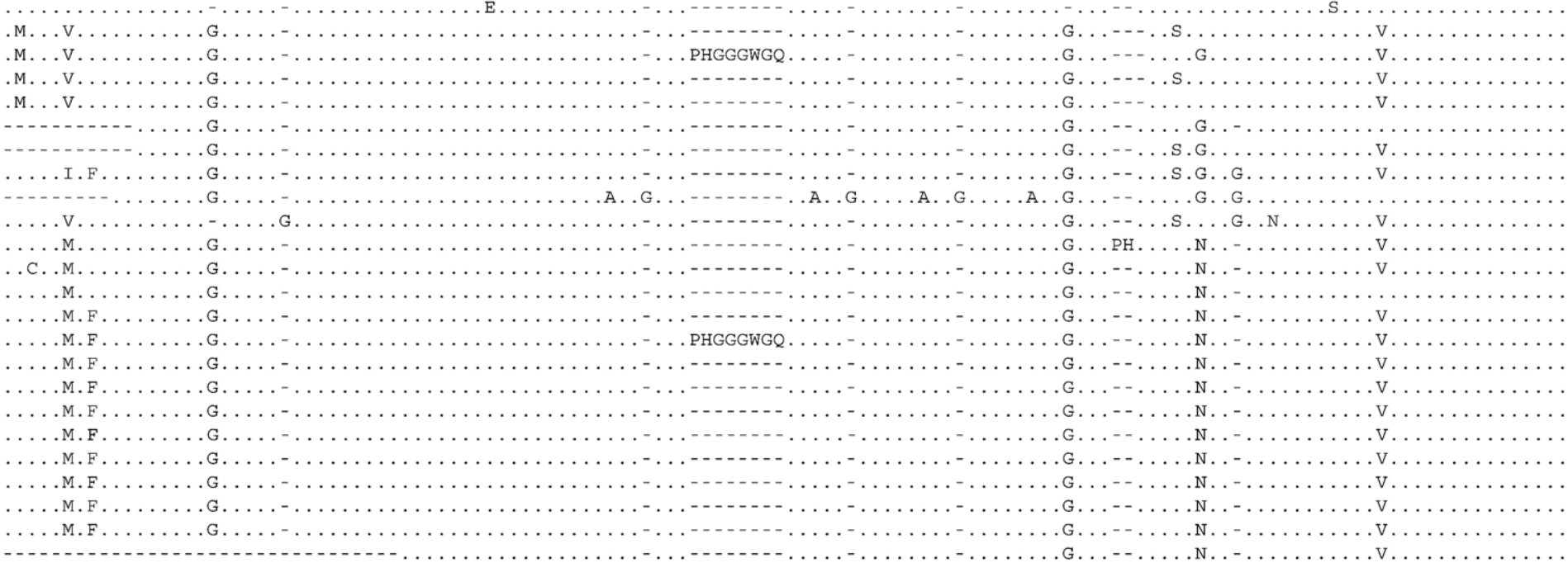

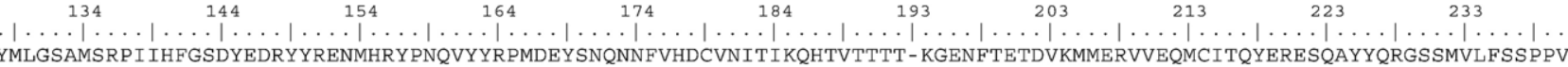

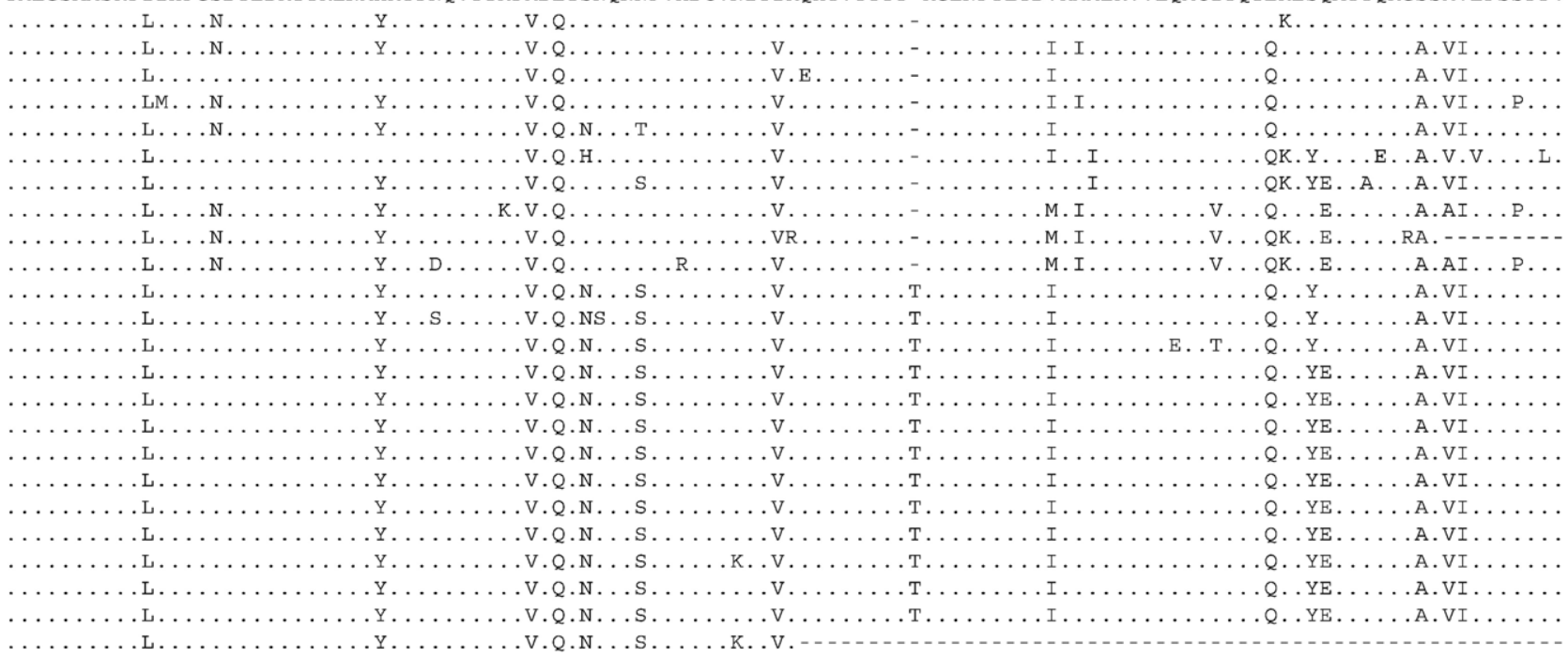



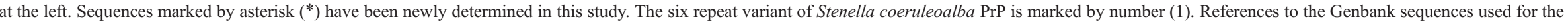


NM001008687, Mustela vison S46825, Felis catus AY573555, Canis familiaris AF042843, Physeter catodon AY133054, Tursiops truncatus (2) DQ130070, (3) DQ130069, (4) AY964056, (5) AF117311. 
heterozygosity for alleles with five and six repeats. The PCR product showed a double band in ethidium bromide-stained $2.8 \%$ agarose gel; cloning and sequencing revealed that a $24 \mathrm{bp}$ extra repeat was inserted between the second and third repeat units of the wild-type sequence. The additional repeat had the same nucleotide sequence of the second repeat unit. Repeat length polymorphism is a frequent mutational process in the eutherian prion gene. Events leading to expansion and contraction of repeats are thought to involve unequal crossing-over and replication slippage (Collinge, 2001). Extension of the normal number of five repeats with one to nine copies has been observed in human prion disease kindreds, and addition of repeat units promotes the early onset of prion disease (Collinge, 2001). A reduction in the repeat number to four does not lead to prion disease, but an elderly patient suffering from a progressive dementia consistent with CJD was reported to carry heterozygosis for three repeats (Beck et al., 2001). A variant containing only three instead of the usual five copies of repeats has been described in goats (Goldmann et al., 1998). One goat heterozygous for the polymorphism and challenged experimentally with scrapie succumbed after an unusually long incubation period. In cattle, three PrP isoforms are known, ranging from five to seven repeats, unlikely associated with BSE (Hunter et al., 1994; Neibergs et al., 1994; Humeny et al., 2002; Sander et al., 2004). Homozygosis for four or seven repeats occurs in several other mammalian species and alleles, with two repeats quite common in the lemur and the squirrel (van Rheede et al., 2003), even if it is not known whether homozygotes are viable. Cetacean repeats respected the eutherian consensus sequence $\mathrm{P}(\mathrm{Q} / \mathrm{H}) \mathrm{GGG}(\mathrm{G} /-) \mathrm{WGQ}$ : the first repeat had $\mathrm{Q}$ at position 2 and a GGGG run and the following ones had $\mathrm{H}$ at position 2 and GGG. In the examined cetaceans, a GGGG track occurred in the last repeat; indeed, this is a common finding also in some terrestrial mammal PrPs and is indicative of repeat homogenization between maritime and terrestrial mammals. A truncated repeat is inserted in P. catodon (after position 91). In this species, the deletion may have been triggered by glycine runs on both sites of the WGQ triplet, as present in the last repeats in other placentals (van Rheede et al., 2003). Such a feature was not present in the other related members of the suborder Odontoceti considered in this study, suggesting that the deletion occurred after the divergence of the family Physeteridae. The nucleotide sequence of the cetacean repeat region is shown in Fig. 2. The histidine residues of the internal octarepeats were generally encoded by $c a c$, but cat was used in the second repeat of $Z$. cavirostris and in the third repeat of $P$. catodon and $G$. griseus. Triplets coding the first glycine showed a conserved behaviour respecting the same run in all the examined species: gga was used in the first repeat and ggt in the following ones. The ggg triplet encoded the second glycine in the first nona-repeat, while ggt encoded the same amino acid in the other units, but $g g c$ was also used in B. physalus. The third glycine triplet in all the examined cetaceans changed with repeat length, being gga or $g g c$ according to the presence of nine or eight residues, respectively. This variation can be associated with the fact that in mammals almost all glycine residues preceding the tryptophan are encoded by ggc (van Rheede et al., 2003). The triplet coding for the last glycine was quite inhomogeneous: ggt, gga and ggc were used, even if the third and fifth repeats showed conservation of ggt in all the considered species. Similarly, the terminal glutamine residue was usually encoded by cag, but it could also be encoded by caa except in $P$. catodon.

\subsubsection{C-terminal region}

In the C-terminal region (the proteinase-resistant part of $\operatorname{PrP}$ ), important functional residues are present, like the
I

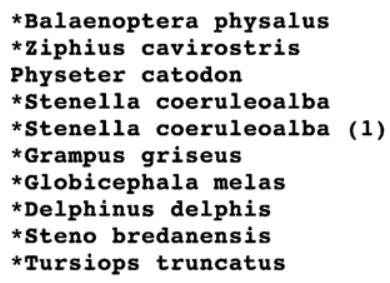

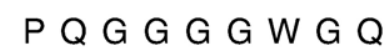

CCCCAGGGAGGGGGAGGCTGGGGTCAG

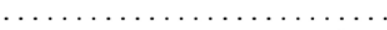

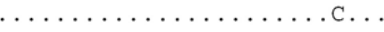
n.m. $\cdots \cdots \cdots \cdots \cdots \cdots \cdots$ $\ldots \ldots \ldots \ldots$ $\ldots \ldots \ldots \ldots \ldots \ldots$ $\ldots \ldots \ldots \ldots \ldots \ldots \ldots \ldots$ $\ldots \ldots \ldots \ldots \ldots \ldots \ldots$

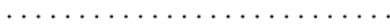

III

P H G G G W G Q

CCCCACGGTGGTGGCTGGGGTCAG $\ldots \ldots \ldots \ldots \ldots \ldots$ . $\ldots \ldots \ldots \ldots \ldots \ldots \ldots$ $\ldots \ldots \ldots \ldots \ldots \ldots$ . Ү... . $\ldots \ldots \ldots \ldots \ldots$ $\ldots \ldots \ldots \ldots \ldots \ldots \ldots$ $\ldots \ldots \ldots \ldots \ldots$ $\ldots \ldots \ldots \ldots \ldots$
II

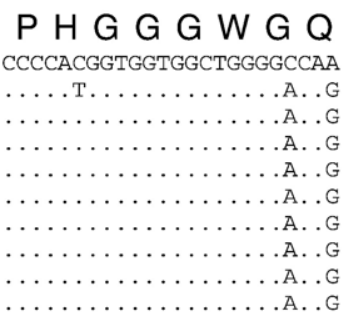

IV

P H G G G W G Q

CCCCACGGTGGTGGCTGGGGTCAG

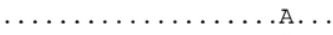
$\ldots \ldots \ldots \ldots \ldots \ldots$ A.

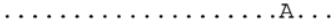

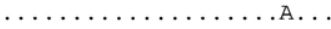

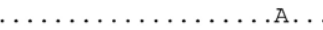
.......... $\ldots \ldots \ldots \ldots \ldots \ldots \ldots$ A.

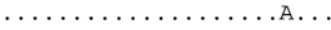

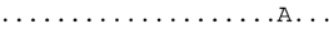

\#

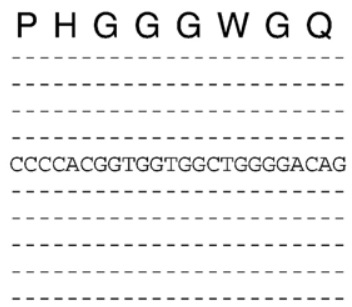
V CCCCATGGTGGCGGAGGCTGGGGTCA $\ldots \ldots \ldots \ldots$. . . . . . . . $\ldots \ldots \ldots$ T. $\ldots \ldots \ldots$ $\ldots \ldots \ldots \ldots$ T. . . . $\ldots \ldots$ т. $\ldots \ldots \ldots \ldots$ ..... $\ldots \ldots \ldots \ldots$ т. $\ldots \ldots \ldots \ldots$ $\ldots \ldots \ldots \ldots$ т..........

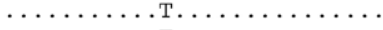
. $\ldots \ldots \ldots$ T. . .

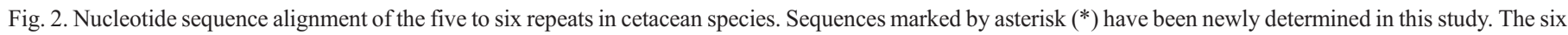

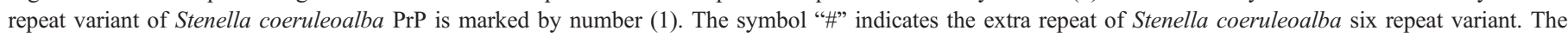
additional repeat has the same nucleotide sequence of the second repeat. 
hydrophobic region (amino acids 115-126), the glycosylation sites, two cysteines forming a disulfide bridge and a serine at position 231, binding the GPI anchor. This region is structured by the presence of $\alpha$-helices and $\beta$-strands.

Next to the repeat region, maritime mammal sequences revealed a deletion of codon 100, which led to a cetacean variant of the motif QWXKP (positions 98-102) that is well conserved in mammals. The only other species presenting this deletion is the hippopotamus: the molecular relationship of whales with the hippopotamus and ruminants in Cetartiodactyla is well-established now, although the existence of a whalehippo clade is still debated among morphologists (Gatesy and O'Leary, 2001; Boisserie et al., 2005). Lysine 110 was present in all the analysed cetacean species. This amino acid seems to be very conserved in all mammalian species; this could be consistent with its supposed functional role as a posttranslational cleavage site of $\operatorname{PrP}^{\mathrm{C}}$ (Harris, 1999). According to our findings, the $\operatorname{PrP}$ of $Z$. cavirostris was the only cetacean PrP with the same amino acid (methionine) at position 112 as in humans. The presence of methionine or valine might play a central role in species-barrier restrictions (Schätzl et al., 1995). Moreover, residue 112 is important in TSE diagnosis since it is involved in the formation of the epitope for antibody 3F4. This specific antibody has been shown to bind exclusively to $\operatorname{PrP}^{\mathrm{Sc}}$ with a methionine at position 112 (Bolton et al., 1991; Kanyo et al., 1999).
The hydrophobic region was conserved in all cetacean sequences reported in this study. The hydrophobic stretch is perfectly conserved also in avian and reptiles $\operatorname{PrP}$ and is considered a PrP signature. It probably plays a key role in $\mathrm{PrP}^{\mathrm{C}}$ conversion to $\operatorname{PrP}^{\mathrm{Sc}}$ (Salmona et al., 1999). Deletion of the $\mathrm{N}$-terminus is able to prevent conformational transition to $\operatorname{PrP}^{\mathrm{Sc}}$ only if it includes this hydrophobic region (Muramoto et al., 1996).

At position 143, situated immediately before $\alpha$-helix 1 (H1) and believed to be implicated in human susceptibility cattlederived prion (Krakauer et al., 1996), a serine residue was present in all species, relating cetaceans to most ruminants of the subfamily Bovinae and to species like the pig, the hippopotamus and the rabbit. A substitution unique to B. physalus was present at codon 159 (Asn-Ser), in close proximity to regions of $\operatorname{PrP}$ with a secondary structure (starting of $\beta$-sheet 2 ). Remarkably, this codon is usually well conserved in most species; an identical polymorphism has been identified in the squirrel monkey (van Rheede et al., 2003), and another coding mutation (Asn-Asp) was found in some canine species, including the domestic dog (Wopfner et al., 1999). Sequence position 159 of canine PrP is likely a candidate in association with positions 103 and 177 for contributing to the implicated species barrier for TSE transmission from cattle to canine species (Lysek et al., 2004). B. physalus PrP sequence carried a serine at position 171 , the same substitution has been detected

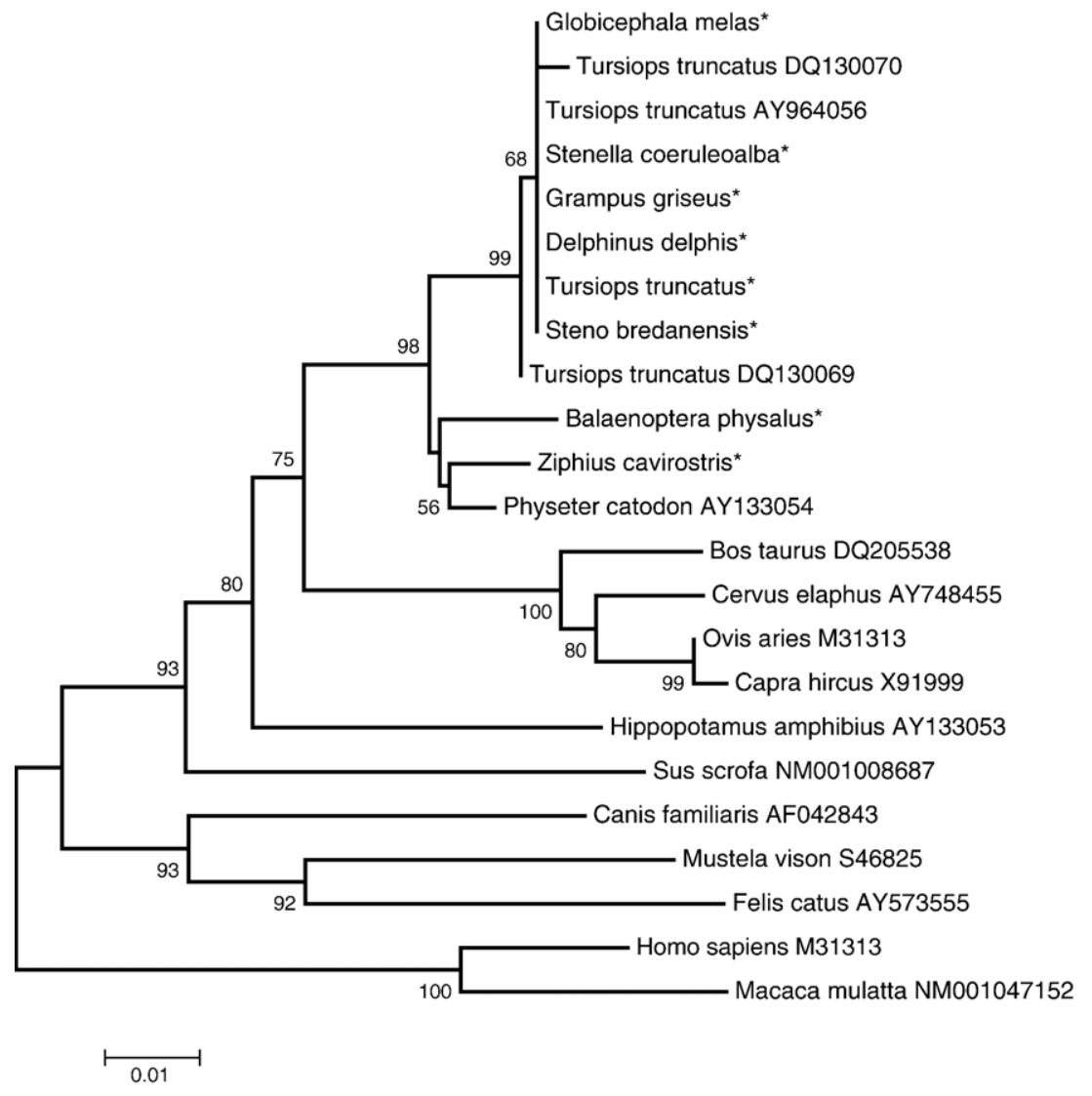

Fig. 3. Phylogenetic tree of similarity among cetacean and other mammalian $\operatorname{Pr} P$ gene sequences. Sequences marked by asterisk $(*)$ have been newly determined in this study. Genbank accession numbers of known mammalian $\operatorname{Pr} P$ sequences are indicated. Bootstraps values $>50$ (1000 replicates) are indicated at the internal nodes. The scale bar represents the percentage of nucleotide differences. 
as a polymorphism in some human populations (Mead et al., 2003). At position 174, structurally the second amino acid of the $\alpha$-helical 2 (H2) region, all the analysed cetaceans showed a serine also found in the pig, banteng (Bos javanicus), lama, camel and rabbit. The cysteines at positions 179 and 214, forming the disulfide bridge, were well conserved in cetaceans, as in all mammals, birds and turtles. The disulfide bridge is essential for stabilizing the PrP structure. Substitutions of these residues result in insolubilization of the protein (Maiti and Surewicz, 2001). The two $N$-glycosylation sites at codon 181 and 197 (Rogers et al., 1990) were conserved in all cetaceans. $\mathrm{N}$-linked sugars preserve the extracellular PrP surface from proteases and non-specific protein interactions (Rudd et al., 2001). The reported presence of lysine instead of asparagine at position 181 (Wopfner et al., 1999; Yanming et al., 2006) in T. truncatus was not present in the two bottle-nose dolphins analysed in the present study. These results suggest that position 181 is polymorphic in the bottle-nose dolphin. The frequency of the $181 \mathrm{~N}$ and $181 \mathrm{~K}$ alleles is not known, but we can speculate that neither is rare if they have been found in a small number of animals. To the authors' knowledge, there are no other species with a $\operatorname{Pr} P$ polymorphism causing the loss of the first glycosylation site, so it would be interesting to investigate its functional consequences. Transgenic mice carrying the PrP substitution threonine for asparagine 181, which eliminates the first glycosylation site, show that the lack of glycans does not influence PrP maturation and stability and that the presence of one sugar chain is sufficient for trafficking to the cell membrane (Cancellotti et al., 2005). In the other cetacean species examined in this study, the N-linked glycosylation sites were found to be conserved. Nonetheless, the overall identity of the $\operatorname{Pr} P$ genes of the family Delphinidae does not rule out the possibility of the presence of this polymorphism also in other species: collecting further data on a larger number of samples could indicate whether it has a specific significance in marine mammals. Two silent mutations at codon $188(a c g \rightarrow a c a)$ and $201(a c g \rightarrow a c a)$ were found in heterozygosis in B. physalus: cloning showed that they were located on two different haplotypes. At positions 190-193 four threonine residues are present in the prion protein of all mammals so far characterized, while the cetacean sequences showed the insertion of a fifth threonine. This insertion localizes in the $\mathrm{H} 2$ region between the two glycosylation sites, a conserved region outside the structural domain which could be important for the conversion process of PrP isoforms (Wopfner et al., 1999). This variation could raise questions about the three-dimensional structure and flexibility of the prion protein in cetaceans. Isoleucine occurred at position 203 of all determined cetacean PrP sequences. The CJD-related mutation $V 203 I$ seems to be an extremely rare polymorphism in humans (Peoc'h et al., 2000) while most eutherian $\operatorname{Pr} P$ genes carry this variant (van Rheede et al., 2003). Position 212, implicated in Gerstmann-Straussler-Scheinker disease (GSS) in human (Q212P) (Piccardo et al., 1998), was not conservative in Z. cavirostris. Variant 212E occurred in this cetacean species; the same replacement has been observed exclusively in some microbats so far. The prion protein sequence of $Z$. cavirostris was the only identified cetacean gene carrying a threonine at codon 215. Members of orders Rodentia (i.e. Syrian hamster), Macroscelidea and Chiroptera are also known to carry this amino acid. A polymorphism involving codon 215 has been described in the goat (I215L) (Zhang et al., 2004). Position 215 forms with 168, 172, and 219 the epitope for the binding of protein $\mathrm{X}$. An arginine residue was present at the highly variable position 220 in all the examined cetaceans. Position 223, immediately preceding the GPI anchor site, showed variability in cetacean species. Members of the family Delphinidae carried a glutamic acid residue, while a glutamine occurred in the species belonging to the families Balaenopteridae, Ziphidae and Physeteridae. This region forms a flexible linkage to the GPI anchor (Riek et al., 1996; Liu et al., 1999). The serine residue at position 231, where the GPI anchor is attached, was strictly conserved in all cetaceans.

\subsection{Phylogenetic analysis of cetacean PrP gene}

Expanding the spectrum of mammalian prion genes may improve our ability to reconstruct ancient phylogenetic nodes and enhance our understanding of fixed mutational events during the evolution of the prion protein. Fig. 3 shows the phylogenetic tree resulting from an analysis of the cetacean $\operatorname{Pr} P$ gene sequences, together with reported sequences of some ungulates, carnivores and primates. $\operatorname{Pr} P$ gene phylogenesis mirrored species phylogenesis supporting the association of cetaceans with the hippopotamus and ruminants in the order Cetartiodactyla. Analysis of additional species will help to reconstruct the prion sequence at the time that cetaceans diverged from artiodactyls 60 millions years ago.

\subsection{Conclusions}

- This work adds so far unreported $\operatorname{Pr} P$ sequences of cetaceans to the collection of known prion protein genes.

- Cetacean PrPs present typical features of eutherian PrPs.

- $\operatorname{Pr} P$ gene evolution follows the evolution of the species.

- The $\operatorname{Pr} P$ gene of cetaceans is very close to species where natural forms of TSEs are known.

- From an analysis of the sequences and the phylogenesis of the $\operatorname{Pr} P$ gene, susceptibility to or occurrence of prion diseases in cetaceans cannot be excluded.

\section{Acknowledgements}

We would like to thank the Mediterranean Marine Mammals Tissue Bank of the Department of Experimental Veterinary Sciences (University of Padua) and especially Prof. Bruno Cozzi and Dr. Camilla Butti for sample contribution.

\section{References}

Aguzzi, A., Montrasio, F., Kaiser, P.S., 2001. Prions: health scare and biological challenge. Nature reviews. Mol. Cell Biol. 2, 118-126.

Beck, J.A., et al., 2001. Two-octapeptide repeat deletion of prion protein associated with rapidly progressive dementia. Neurology 57, 354-356.

Belt, P.B.G.M., Muileman, I.H., Schreuder, B.E.C., Bos-de Ruijter, J., Gielkens, A.L.J., Smits, M.A., 1995. Identification of five allelic variants of the sheep 
$\operatorname{PrP}$ gene and their association with natural scrapie. J. Gen. Virol. 76, 509-517.

Billeter, M., Riek, R., Wider, G., Hornemann, S., Glockshuber, R., Wuthrich, K., 1997. Prion protein NMR structure and species barrier for prion diseases. Proc. Natl. Acad. Sci. U. S. A. 94, 7281-7285.

Billinis, C., et al., 2002. Prion protein gene polymorphisms in natural goat scrapie. J. Gen. Virol. 83, 713-721.

Boisserie, J.R., Lihoreau, F., Brunet, M., 2005. The position of Hippopotamidae within Cetartiodactyla. Proc. Natl. Acad. Sci. U. S. A. 102, 1537-1541.

Bolton, D.C., et al., 1991. Molecular location of a species-specific epitope on the hamster scrapie agent protein. J Virol. 65, 3667-3675.

Bossers, A., Schreuder, B.E.C., Muileman, I.H., Belt, P.B.G.M., Smits, M.A., 1996. PrP genotype contribute to determining survival times of sheep with natural scrapie. J. Gen. Virol. 77, 2669-2673.

Brown, D.R., et al., 1997. The cellular prion protein binds copper in vivo. Nature $390,684-687$.

Bueler, H., et al., 1993. Mice devoid of PrP are resistant to scrapie. Cell 73, 1339-1347.

Cancellotti, E., et al., 2005. Altered glycosylated PrP proteins can have different neuronal trafficking in brain but do not acquire scrapie-like properties J. Biol. Chem. 280, 42909-42918.

Collinge, J., 2001. Prion diseases of humans and animals: their causes and molecular basis. Annu. Rev. Neurosci. 24, 519-550.

Cotto, E., Andre, M., Forgue, J., Fleury, H.J., Babin, P.J., 2005. Molecular characterization, phylogenetic relationships, and developmental expression patterns of prion genes in zebrafish (Danio rerio). FEBS J. 272, 500-513.

Felsenstein, J., 1981. Evolutionary trees from DNA sequences: maximum likelihood approach. J. Mol. Evol. 17, 368-376.

Gabriel, J.M., Oesch, B., Kretzschmar, H., Scott, M., Prusiner, S.B., 1992 Molecular cloning of a candidate chicken prion protein. Proc. Natl. Acad. Sci. U. S. A. 89, 9097-9101.

Gatesy, J., O’Leary, M.A., 2001. Deciphering whale origins with molecules and fossils. Trends Ecol. Evol. 16, 562-570.

Gill, A.C., et al., 2000. Post-translational hydroxylation at the N-terminus of the prion protein reveals presence of PPII structure in vivo. EMBO J. 19, 5324-5331.

Goldmann, W., Chong, A., Foster, J., Hope, J., Hunter, N., 1998. The shortest known prion protein gene allele occurs in goats, has only three octapeptide repeats and is nonpathogenic. J. Gen. Virol. 79, 3173-3176.

Hamir, A.N., et al., 2006. Preliminary observations of genetic susceptibility of elk (Cervus elaphus nelsoni) to chronic wasting disease by experimental oral inoculation. J. Vet. Diagn. Invest. 18, 110-114.

Harris, D.A., 1999. Cell biological studies of the prion protein. Curr. Issues Mol. Biol. 1, 65-75.

Horiuchi, M., Priola, S.A., Chabry, J., Caughey, B., 2000. Interactions between heterologous forms of prion protein: binding, inhibition of conversion, and species barriers. Proc. Natl. Acad. Sci. U. S. A. 97, 5836-5841.

Humeny, A., Schiebel, K., Seeber, S., Becker, C.M., 2002. Identification of polymorphisms within the bovine prion protein gene (Prnp) by DNA sequencing and genotyping by MALDI-TOF-MS. Neurogenetics 4, 59-60.

Hunter, N., Goldmann, W., Smith, G., Hope, J., 1994. Frequencies of $\operatorname{Pr} P$ gene variants in healthy cattle and cattle with BSE in Scotland. Vet. Rec. 17, 400-403.

Johnson, R.T., Gibbs Jr., C.J., 1998. Creutzfeldt-Jakob disease and related transmissible spongiform encephalopathies. N. Engl. J. Med. 339, 1994-2004.

Kanyo, Z.F., et al., 1999. Antibody binding defines a structure for an epitope that participates in the $\operatorname{PrP}^{\mathrm{C}} \rightarrow \mathrm{PrP}^{\mathrm{Sc}}$ conformational change. J. Mol. Biol. 293, 855-863.

Kirkwood, J.K., Cunningham, A.A., 1994. Epidemiological observations on spongiform encephalopathies in captive wild animals in the British Isles. Vet. Rec. 135, 296-303.

Kocisko, D.A., Priola, S.A., Raymond, G.J., Chesebro, B., Lansbury Jr., P.T., Caughey, B., 1995. Species specificity in the cell-free conversion of prion protein to protease-resistant forms: a model for the scrapie species barrier. Proc. Natl. Acad. Sci. U. S. A. 92, 3923-3927.

Krakauer, D.C., Pagel, M., Southwood, T.R.E., Zanotto, P.M.A., 1996 Phylogenesis of prion protein. Nature 380, 675

Kumar, S., Tamura, K., Nei, M., 2004. MEGA3: integrated software for Molecular Evolutionary Genetics Analysis and sequence alignment. Brief. Bioinform. 5, 150-163.
Liu, H., et al., 1999. Solution structure of Syrian hamster prion protein rPrP (90-231). Biochemistry 38, 5362-5377.

Lysek, D.A., Nivon, L.G., Wuthrich, K., 2004. Amino acid sequence of the Felis catus prion protein. Gene 341, 249-253.

Maiti, N.R., Surewicz, W.K., 2001. The role of disulfide bridge in the folding and stability of the recombinant human prion protein. J. Biol. Chem. 276, 2427-2431

Martin, T., Hughes, S., Hughes, K., Dawson, M., 1995. Direct sequencing of PCR amplified pig PrP genes. Biochem. Biophys. Acta 1270, 211-214.

Mead, S., et al., 2003. Balancing selection at the prion protein gene consistent with prehistoric kurulike epidemics. Science 300, 640-643.

Muramoto, T., Scott, M., Cohen, F.E., Prusiner, S.B., 1996. Recombinant scrapie-like prion protein of 106 amino acids is soluble. Proc. Natl. Acad. Sci. U. S. A. 93, 15457-15462.

Neibergs, H.L., Ryan, A.M., Womack, J.E., Spooner, R.L., Williams, J.L., 1994. Polymorphism analysis of the prion gene in BSE-affected and unaffected cattle. Anim. Genet. 25, 313-317.

Oesch, B., et al., 1985. A cellular gene encodes scrapie PrP 27-30 protein. Cell 40, 735-746.

Oidtmann, B., Simon, D., Holtkamp, N., Hoffmann, R., Baier, M., 2003. Identification of cDNAs from Japanese pufferfish (Fugu rubripes) and Atlantic salmon (Salmo salar) coding for homologues to tetrapod prion proteins. FEBS Lett. 538, 96-100.

O’Rourke, K.I., et al., 1999. PrP genotypes of captive and free-ranging Rocky Mountain elk (Cervus elaphus nelsoni) with chronic wasting disease. J. Gen. Virol. 80, 2765-2769.

Pauly, P.C., Harris, D.A., 1998. Copper stimulates endocytosis of the prion protein. J. Biol. Chem. 273, 33107-33110.

Peden, A.H., Ironside, J.W., 2004. Review: pathology of variant CreutzfeldtJakob disease. Folia Neuropathol. 42 (Suppl. A), 85-91.

Peoc'h, K., Guerin, C., Brandel, J., Launay, J., Laplanche, J., 2000. First report of polymorphisms in the prion-like protein gene (PRND): implications for human prion diseases. Neurosci. Lett. 286, 144-148.

Piccardo, P., et al., 1998. Phenotypic variability of Gerstmann-StrausslerScheinker disease is associated with prion protein heterogeneity. J. Neuropathol. Exp. Neurol. 57, 979-988.

Premzl, M., Bozic, P., Gamulin, V., 2000. PRNP octarepeat allele genotype frequencies among the modern and rare cattle breeds in Croatia. Anim. Genet. 31, 408-409.

Prusiner, S.B., 1982. Novel proteinaceous infectious particles cause scrapie. Science $216,136-144$

Prusiner, S.B., 1991. Molecular biology of prion diseases. Science 252, 1515-1522. Prusiner, S.B., 1998. Prions. Proc. Natl. Acad. Sci. U. S. A. 13363-13383.

Riek, R., Hornemann, S., Wider, G., Billeter, M., Glockshuber, R., Wuthrich, K., 1996. NMR structure of the mouse prion protein domain $\operatorname{PrP}(121-321)$. Nature 382, 180-182.

Rivera-Milla, E., Stuermer, C.A., Malaga-Trillo, E., 2003. An evolutionary basis for scrapie disease: identification of a fish prion Mrna. Trends Genet. 19, $72-75$.

Rogers, M., Taraboulos, A., Scott, M., Groth, D., Prusiner, S.B., 1990. Intracellular accumulation of the cellular prion protein after mutagenesis of its Asn-linked glycosylation sites. Glycobiology 1, 101-109.

Rudd, P.M., Wormald, M.R., Wing, D.R., Prusiner, S.B., Dwek, R.A., 2001. Prion glycoprotein: structure, dynamics, and roles for the sugars. Biochemistry 40, 3759-3766.

Saitou, N., Nei, M., 1987. The neighbor-joining method: a new method for reconstructing phylogenetic trees. Mol. Biol. Evol. 4, 406-425.

Salmona, M., et al., 1999. Molecular determinants of the physicochemical properties of a critical prion protein region comprising residues 106-126. Biochem. J. 342, 207-214

Sander, P., et al., 2004. Analysis of sequence variability of the bovine prion protein gene (PRNP) in German cattle breeds. Neurogenetics 5, 19-25.

Schätzl, H.M., Da Costa, M., Taylor, L., Cohen, F.E., Prusiner, S.B., 1995. Prion protein gene variation among primates. J. Mol. Biol. 245, 362-374.

Scott, M., et al., 1993. Propagation of prions with artificial properties in transgenic mice expressing chimeric $\operatorname{Pr} P$ genes. Cell 73, 979-988.

Simonic, T., Duga, S., Strumbo, B., Asselta, R., Ceciliani, F., Ronchi, S., 2000. cDNA cloning of turtle prion protein. FEBS Lett. 469, 33-38. 
Stahl, N., Borchelt, D.R., Prusiner, S.B., 1990. Differential release of cellular and scrapie prion proteins from cellular membranes by phosphatidylinositolspecific phospholipase C. Biochemistry 29, 5405-5412.

Strumbo, B., Ronchi, S., Boli, L.C., Simonic, T., 2001. Molecular cloning of the cDNA coding for Xenopus laevis prion protein. FEBS Lett. 508, 174-179.

Suzuki, T., Kurokawa, T., Hashimoto, H., Sugiyama, M., 2002. cDNA sequence and tissue expression of Fugu rubripes prion protein-like: a candidate for the teleost orthologue of tetrapod PrPs. Biochem. Biophys. Res. Commun. 294, 912-917.

Telling, G.C., et al., 1994. Transmission of CJD from humans to transgenic mice expressing chimeric human-mouse prion proteins. Proc. Natl. Acad. Sci. U. S. A. 91, 9936-9940.

Telling, G.C., et al., 1995. Prion propagation in mice expressing human and chimeric PrP transgenes implicates the interaction of cellular PrP with another protein. Cell 83, 79-90.

Udenfriend, S., Kodukula, K., 1995. How glycosylphosphatidylinositolanchored membrane proteins are made. Annu. Rev. Biochem. 64, 563-591.

van Rheede, T., Smolenaars, M.M., Madsen, O., de Jong, W.W., 2003. Molecular evolution of the mammalian prion protein. Mol. Biol. Evol. 20, 111-121.

Viles, J.H., Cohen, F.E., Prusiner, S.B., Goodin, D.B., Wright, P.E., Dyson, H.J., 1999. Copper binding to the prion protein: structural implications of four identical cooperative binding sites. Proc. Natl. Acad. Sci. U. S. A. 96, 2042-2047.
Vorberg, I., Groschup, M.H., Pfaff, E., Priola, S.A., 2003. Multiple amino acid residues within the rabbit prion protein inhibit formation of its abnormal isoform. J. Virol. 77, 2003-2009.

Weissmann, C., 1999. Molecular genetics of transmissible spongiform encephalopathies. J. Biol. Chem. 274, 3-6.

Wopfner, F., et al., 1999. Analysis of 27 mammalian and 9 avian PrPs reveals high conservation of flexible regions of the prion protein. J. Mol. Biol. 289 1163-1178.

Wu, C., Pang, W., Zhao, D., 2006. Amino acid sequence of the Amur tiger prion protein. Virus Res. 121, 93-96 (Epub 2006 Jun 15).

Yang, J.M., et al., 2005. Comparative analysis of the prion protein open reading frame nucleotide sequences in peacock and parakeet. Virus Genes. 30, 193-196.

Yanming, S., Pang, W., Deming, Z., 2006. Analysis of the prion protein gene $(P R N P)$ in bottle-nosed dolphin. Asian J. Anim. Vet. Adv. 1, 49-51.

Zhang, L., Li, N., Wang, Q.G., Fan, B.L., Meng, Q.Y., Wu, C.X., 2002. Cloning and sequencing of quail and pigeon prion genes. Anim. Biotechnol. 13, 159-162.

Zhang, L., Li, N., Fan, B., Fang, M., Xu, W., 2004. PRNP polymorphisms in Chinese ovine, caprine and bovine breeds. Anim. Genet. 35, 457-461 (Erratum in: Anim. Genet. 2005 Feb; 36(1):93). 